\title{
MIGRANT LABOUR AND ISSUES ON OUTSOURCING SYSTEM IN MALAYSIA.
}

\author{
Dr. Rohani Abdul Rahim, Muhammad Afiq bin Ahmad Tajuddin \& Kamaruddin bin Hj. Abu Bakar \\ Faculty of Law \\ Universiti Kebangsaan Malaysia
}

and

\author{
Mohammad Nizamuddin Bin Abdul Rahim \\ Faculty of Business and Entrepreneur \\ Universiti Malaysia Kelantan
}

Most of the registered migrant labours (more than 2.3 million in year 2013) send to Malaysia are being employed in various work sectors including construction, manufacturing, plantation, agriculture and services. While the source countries are from Bangladesh, Indonesia, Thailand, India, China, Sri Lanka, Pakistan and Vietnam. The fundamental concern is on migrant labours status because they remain the employees of those outsourcing companies and not the factories where they work. This is because work contract are made between the out sourcing companies and the factories owners (the employers) and not between the employees and the employers. This leaves great consequences on the employees. Legally, in labour relations, the lack on privity of contract between the employee and employer raise the question of legal responsibility and liability between the contracting parties. This paper will deal further on the receiving government policy, law and practice as well as the responsibility and liability of the outsourcing companies towards the migrant labours and the employers.

Keywords: Outsourcing, migrant labour, responsibility and liability.

\section{INTRODUCTION}

Malaysia is on the verge of implementing her Tenth Malaysia Plan (10MP 2011-2015). It aspire the Government Transformation Program and the New Economic Model (Economic Transformation Program-ETP), premised on high income, inclusiveness and sustainability. National budget were allocated to all economic sectors by the Finance Ministry to pursue Malaysia ambition aiming to achieve the developed country status. It sets the stage for a major structural transformation that a high-income economy requires. The Plan contains new policy directions, strategies and programs that enable the country to emerge as a high income nation. The five basic strategies underline by this plan are aimed to elevate Malaysia economy and the nation standard of living. The five strategies are, to Increase the value in country economy; improve knowledge abilities and innovation, and inculcate first-world minded; handle continuously socioeconomic inequalities; improve level and ability of living quality and to strengthen the institution and country's implementation(2010,10MP). Approaching 2015, time is running out to ensure what have been planned can be realize within the time frame. However, this should be seen as a continuous effort in achieving high-income status by 2020. The Government defines high income as a per capita income USD15,000 or RM48,000 in 2020, as currently defined by the World Bank's. At present Malaysia's per capita gross national income (GNI) is about RM23,700 or USD6,700. For purpose of achieving high-income status by 2020, the annual GDI real growth rate should be stabilized at least 6 per cent between 2011 and 2020.

Referring to the characteristics possessed by the developed nation, Malaysia is focusing on developing the followings that are;

This is an Open Access article distributed under the terms of the Creative Commons Attribution License 4.0, which permits unrestricted use, distribution, and reproduction in any medium, provided the original work is properly cited. 
"1. A large and thriving services sector, to supplement the nation's historical strengths in oil and gas, agriculture and manufacturing;

2. A balanced economy, with significant contributions from private consumption and investment as well as from government spending and exports. In developed countries domestic demand typically accounts for 50 to 70 per cent of GDP. In Malaysia it is currently 53 per cent; and

3. Productivity levels similar to those of other leading Asian economies. Achieving this will require developing an economy that is more heavily driven by skills, innovation and knowledge." (2010, 10MP)

\section{EFFECTING THE PLAN}

Planning is essential in order to strategize and move forward in achieving what have being planned. A clear and realistic planning is important not only as a roadmap but it will ensure Malaysia preparedness to move ahead of time. For that reason, to ensure the implementation of this ETP, the country need skilled, motivated and committed labour to realized the planning. For this purpose the country needs support from her citizen and other means of labour resources that can help to generate development. Over the last two decades, Malaysian labour markets experienced rapid increases in human capital and education levels, low unemployment and labour force participation, increased diversification across sectors and continued importance of several export and domestic service sectors. Malaysia's rapid economic growth accompanied with labour market shortages for unskilled labours continue to attract foreign labours from neighbouring countries. The differences in growth differentials and overall educational gaps between the labour forces of Malaysia and its more populous neighbours, such as Indonesia and the Philippines, and other Asia countries (India, Myanmar, Bangladesh) are the key pull and push factors that fuel the current migration patterns.

At the same time there is large inflow of foreign labours that attributable to demand factors in the domestic labour market in labour intensive sectors, relative shortage of unskilled labours and remarkable economic success of Malaysia relative to neighbouring countries (The World Bank, 2013).The Memorandum of Understandings signed by Malaysia, which differs from country to country, cover issues such as minimum wages, the specific sector where the labours will be employed, housing, legal status, duration, etc.

In this paper, the focus is on to find out some of the issues particularly legal issues that may hinder Malaysia planning in achieving high income, inclusiveness and sustainability economy. In order to achieve such Malaysia should be able to draw most resources including labour, from neighbouring countries to migrate and contribute their labour in return for agreeable wages in terms of remittance. There are many reasons for their keenness to come and work, particularly because of the country economic status that generate better monetary exchange rate and the geographical location as well as similar culture that the nation adhere. This keenness is also motivated by the migration chain that existed earlier.

Malaysia economy heavily relies on export-oriented manufacturing and domestic service sectors Mfgtranspequip, Agriculture, Mining, Manufacturing(Mfg) of food-bev-tob, Mfg textile, Mfg wood, Mfg paper-furn, Mfgchem-rub, Metal-machinery-equ, Mfgmeas-med-com, Utilities, Construction, Wholesale-retail, accommodation and restaurant, logistics, post and telecom, finance, real estate, business services, education, health, other services and public administration (World Bank,2013). Foreign labour admission is based on current policies, laws and regulations that changes overtime. Only migrant labour from Bangladesh, Indonesia, Thailand, India, China, Sri Lanka, Pakistan and Vietnam, were admitted. The men were allowed to work in five sectors (restaurant, construction, cable, 
farming and agriculture).The large inflow of these foreign labours is largely attributable to demand factors in the domestic labour market in labour intensive sectors, relative shortage of unskilled labours, and remarkable economic success of Malaysia relative to neighbouring countries. They compose of around $10 \%$ of the labour force. Their inflows can be evidenced in the following Table 1.

Table 1 Total No. Of Legal and Illegal Migrants. (2007 hingga 2012)

\begin{tabular}{|l|l|l|}
\hline Year & Legal Migrants (Milions) & $\begin{array}{l}\text { Illegal Immigrants } \\
\text { (Milions) }\end{array}$ \\
\hline 2007 & 384000 & 1.98 \\
\hline 2008 & 410,000 & 1.92 \\
\hline 2009 & 2.4 & 1.6 \\
\hline 2010 & 1.44 & 1.8 \\
\hline 2011 & $1,135,499$ & 952,859 \\
\hline $\begin{array}{l}2012 \\
(6 P P r o g r a m)\end{array}$ & $2,320,034$ & $\begin{array}{l}\text { Estimated twice } \\
\text { the number of } \\
\text { legal migrants. }\end{array}$ \\
\hline $\begin{array}{l}* \\
(1,016,908 \text { legal labours } \\
\text { plus 1,303,126 illegals } \\
\text { labours legalized) }\end{array}$ & (2) \\
\hline
\end{tabular}

Source: Sumber: Labour Department, Ministry of Human Resource

In 2012, the highest number of foreign labours are from Indonesia $(640,609$ illegal labours and 405,312 legal labours) followed by Bangladeshis (267,803 illegal labours and 132,897 legal labours) while Nepalese (221,617 legitimate labours and 33,437 illegal ones) (MAPO, 2014). In manufacturing sectors, it was established that most of the foreign labours were in large size factories, followed consecutively by small, medium and Micro size factories. While the work sectors involved foreign labour are ICT followed consecutively by Agriculture, Manufacturing, Accommodation and Construction (2013, World Bank).

\section{LABOUR OUTSOURCING}

The word "outsourcing" can generally means contracting out a business processes to third party. Outsourcing includes both foreign and domestic contracting (Hira and Hira.,2008). It can also be used to give similar meaning but variation of terms in different context. This can be seen as follows;

a. transferring employees and assets from one firm to another, but not always (outsourcing)(makelTfair,2013)

b. relocating of business to another country (offshoring) (2004, Davies).

c. the practice of handing over control of public services to for-profit corporations

On the other hand, insourcing means bringing in the process, handled by third-party firms inhouse. However, a contract of service can be provided to another firm without insourcing that business process. Other complex relationship between economic organizations or networks such as nearshoring, crowd sourcing, multi-sourcing and strategic outsourcing (Business Trends Quarterly,2006).In labour outsourcing context, agreement can be made between organizations and/or firms to supply labour services in return (consideration) for some amount of payments. The purpose is to perform better, in their specific competencies and deal with shortage of skill or expertise (Overby,2007). 


\section{OUTSOURCING ISSUES AND IMPLICATIONS}

\section{A. Offer greater budget flexibility and control.}

(i) Outsourcing can lets organizations to pay for only the services they need, when they need them.

(ii) It also reduces the need to hire and train specialized staff, brings in fresh engineering expertise, and reduces capital and operating expenses (Olive, 2004).

(iii) Companies primarily outsource to avoid certain costs - such as peripheral or "non-core" business expenses (Forey, Gall and Jane Lockwood, 2011), high taxes, high energy costs, excessive government regulation/mandates, production and/or labour costs.

(iv) outsource may be greater due to unusually high corporate taxes and mandated benefits, like social security, Medicare, and safety protection (OSHA regulations) (Buchholz and Tod, 2004)

\section{B. Avoid substantial legal liability}

Outsourcing of labour allows the Organization (employer) to avoid substantial liability because the labours are not directly employed by the organization. Thus the latter will not be responsible for any of 'his staff' because the contract is made between the client (organisation) and the supplier (outsourcer). The normal practice prior to outsourcing is that each employee (labour) needs to enter into a contract of employment with the employer that makes the employer responsible for all his staff work-related actions. Since the organization is not having any contract of employment with the labours, the question now is whether there is a contract made between the outsourcer and the labour? If there is one than the legal responsibility is shifted to the outsourcer, not the organization as usual. Otherwise, the labour is left without any legal protection.

\section{A threat to labour security}

In the labour perspective, outsourcing represents a new threat that causes insecurity to them. This is in tune with the globalization process and economic polarization. Globalization integrates world views, ideas, products and other cultural aspects. In 2000, the International Monetary Fund (IMF) identified four basic aspects of globalization: trade and transactions, capital and investment movements, migration and movement of people and the dissemination of knowledge (IMF,2000).It affects and affected by business and work organization, economics, sociocultural resources, and the natural environment. Labour forces are polarized into work classes to meet the industrial needs by structuring of job opportunities. Labour migrants form the low-skill and low wage occupation. Being vulnerable, migrant labour are open to discriminations such as uncertainty in work descriptions and wages. Labour polarization will make outsourcing process much easier because industries can fill up their labour force need. However the setback is it changes the nature of business cycle recoveries. Prior to job polarization employment in routine jobs would recover quickly but now it led to permanent loss of routine jobs (NirJaimovich and Henry E. Siu, 2012)

\section{Legal Issues and Implications}

The foreign labour is said to have less industrial power than citizen labour and have proven to be more flexible labours in an industry that relies on a quick response to changes. At the same time, Malaysia is said to have been effective in preventing the growth of a strong labour movement across Southeast Asia, resulting in a combination of flexible labours with little labour protection (Crinis, 2002).In Malaysia there are certain grey areas for foreign labours on contract, such as overtime rates, trade union membership, unsuitable accommodation and the withholding of labours' passports, which 
are not usually reported. Generally, Malaysia laws are applicable to everyone who is staying within her jurisdictions.

\section{(i) Outsourcing Legislation}

Malaysia has started introducing legislation which transformed the system of recruitment agencies to so called outsourcing agents since July 2005. The issue highlighted is that "the practice of outsourcing agents has gone far beyond what the Cabinet Committee envisioned."(Hector 2013)i.e this includes becoming direct employers of recruited labours, that means they provide accommodation, transportation, paying wages, medical examination and also the obligations to get the necessary insurance coverage for these labours".

The law was only intended to outsource some of the obligations but not fully relieving the employer from their responsibilities. In April 2012, the amended Employment Act 1955 came into effect makes it legal for labour outsourcing agents to remain employers of migrant labours even after the recruited labour started working at the factories. The amendment created the concept 'contractor for labour' and permits these to supply labours to principal employers. The provision can be seen as follows;

\section{Section 2, Employment Act 1955}

"contractor for labour means a person who contracts with a principal, contractor or subcontractor to supply the labour required for the execution of the whole or any part of any work which a contractor or sub-contractor has contracted to carry out for a principal or contractor, as the case may be."

The amended Act contradicted the earlier legislation,(the Private Employment Agencies Act of 1981)because the interpretation to Section 2 above means that when a company pays an outsourcing agency for a labour, the agency becomes the employer for a labour, and regular labour laws would be applicable to the recruitment agency when automatically.

\section{(ii) The Outsourcer/agent as the Employer}

Outsourcing agents hold a particular power over migrant labours because an employment permits ties a labour to a specific industry sector and an employer. often the outsourcing agency. This means that a labour turns his status automatically illegal when he leaves his agent because his/her work permit and visa will be regarded inapplicable (Amnesty International, 2010). This makes them highly dependent on the agents which make them vulnerable to exploitation. Migrants can also be technically illegal when documents are not properly completed or necessary permits are not complied by their agents. As a consequences, migrant worker are expose to criminalization of not having proper documents, overstaying and can be penalize to five years' imprisonment, along with whipping up to six strokes, and fines of MYR 10,000. (UNCHR, 2009)

Recruitment agencies that recruit migrant labours act as middle men between the organization and the labour. This involves the organisation of legal documents (work permits) and accommodation, as well as work contracts. Being in vulnerable position the migrant labour is actually left at the mercy of these middle-men (termed recruitment, outsourcing agencies or temporary work agencies). However 277 licences were given out to outsourcing agencies after the failure to amend the Employment (Amendment) Bill in July 2010 (Hector, 2011). 
(iii) Outsourced labours are not covered by the Collective Bargaining Agreement applicable in their workplaces.

Outsourcing provide protection to the organization and the government but not for the labours. They find that their rights are being exploited and discriminated as a migrant labour. Labours supplied by outsourcing agents are treated differently and often worse than other labours at the same organization or company (Hector,2011)Outsourced agency labours fall outside of collective bargaining agreements and are not entitled to bonuses or allowances (Bormann, S., Krishnan, P., \&Neuner, M., 2009). Some outsourcing agent practices also include paying labours only for the day or hours that they work, without granting regular labour rights such as a paid rest day per week, paid annual leave, paid public holidays, paid sick/hospitalisation leave and maternity leave and benefits (Hector,2011).

\section{(iv) 6p Programme: Legalizing the Migrant labours}

The $6 \mathrm{P}$ programme encompass of registration (pendaftaran), legalisation (pemutihan), amnesty (pengampunan), supervision (pemantauan), enforcement (penguatkuasaan) and deportation (pengusiran)) (NST,2012). It was introduced in June 2011, to handle the large irregular labour force (estimated more than two million). The aim is to assign newly registered migrant labours with jobs, with the help of the Ministry of Human Resources, in five approved sectors, namely, plantation, agriculture, construction, manufacturing and domestic help.

Biometric facilities are used to record the migrants' biodata. This raised privacy concerns and fear among migrants that once detected and biometrically identified for any illegal acts, they will be subject to removal and ban from re-entry. Some 1,3 million undocumented migrants (more than half of the estimated total) had registered for the amnesty, while a further 1 million legal foreign labours was registered for the biometric programme(NST,2012). On 11 April 2012, The 6P programme proceeds from the legalisation enactment and amnesty phase to intensifying the enforcement phase by legalising some 480,000 out of the 1,3 million newly registered illegal migrant labours, leaving over $70 \%$ of those who registered undocumented, without a work permit and thus vulnerable to arrest and deportation. Another 1.7 million remain undocumented labour (UNCHR, 2012).

Those migrants that were returned to their country, have potential of coming again to Malaysia using the Outsourcing system and may probably experience exploitation from unscrupulous labour agents along the recruitment, documentation, transportation, and lodging process.

\section{(v) Malaysia is seen as practising anti-union policy}

Outsourcing recent practice is that migrants are not expressly forbidden to join a labour union but they are discouraged (by inserting certain provision) when requiring them not to be involve as stated in the employment contracts. For example provision such as; "The Employee shall not participate in any political activities and activities of those related to trade union in Malaysia; or instigate others to commit such acts". "The Employee [...] shall not participate in any political activities and activities of those connected with Trade Union in Malaysia. The breach of the restriction will entail a termination of service." (SOMO Research, 2011). This is kind of provision is contrary to the Employment Act (ITUC, 2010). However, if migrant labours still decide to join a union, they cannot become union organisers as the law stipulates that all union officers must be Malaysian citizens. For 
the government, trade unions threaten the national interest and open for wage demands that will induce companies to relocate their business (Bhopal, M., \& Rowley, C., 2010). The use of outsourcing through employment agencies has been justified by a government official as an investment friendly because picket and strike are dealt with at the very beginning at workplace. It was alleged that Anti-union legislation (for migrant labour) that Malaysia possess, caused low unionisation levels in Malaysia (7.45 per cent in 2008)( Rose, Kumar and Ramasamy, 2011). This general "protective" union and probusiness via restrictive labour legislation, limits collective bargaining rights and the right to strike (ITUC, 2010). Thus justified its economic protective policy with the argument that trade unions threaten the national interest with wage demands that induce companies to relocate their business (Bhopal and Rowley, 2011).

\section{(vi) Non Compliance to International Standards and Laws}

Malaysia has signed the four core Labour standards set by the ILO in its Declaration of Fundamental Principles and Rights at Work, e.g. Freedom of Association and Collective Bargaining, The Elimination of Forced and Compulsory Labour, the Elimination of Discrimination in Employment, and the Abolition of Child Labour (ILO, 1998). But rectified the Abolition of Forced Labour Convention (no. 105) in 1990, never ratified the Discrimination (Employment and Occupation) Convention, 1958 (no. 111), the Freedom of Association and Protection of the Right to Organise Convention, 1948 (no. 87) and Migrant Labours (Supplementary Provisions) Convention, 1975) (no.143) (ILO, 2013; SUARAM,2010). At the state level, the Migration for Employment Convention (revised), 1949 (no. 97), which has only been ratified by the state of Sabah (Hassan and George, 2009). Malaysia was also criticized for not agreeing to legally binding ASEAN treaty that is Declaration on the Promotion and Protection of the Rights of Migrant Labours (2007) because that would make the country vulnerable to complaints and lawsuits from other member states (Antara News,2010).

\section{(vii) Exploitation of Migrant labours}

Migrant labours in Malaysia face structural inequalities with regard to labour rights. Starting from the recruitment phase, the ways in which migrant labours are subject to exploitation are diverse. Over 400complaints forward to the Malaysian Trade Union Congress (MTUC) in 2010 indicated some violation to migrant labour rights. This includes non-payment of wages, arbitrary and unexplained wage deductions, breach of working hours, including overtime pay, annual leave, paid public holidays and weekly days of rest. They are employed on a temporary basis and harassed with contract fraud, debt bondage, and subsistence wages for above-average working hours, including structural unpaid overtime, and with obligatory wage deductions for food and accommodation provided by their employment agencies (make IT fair, 2013).

1. Debt Bondage- labour migrant was charge with high recruitment fees up front, or demand pay backs. The amount varies according to the sending countries. These practices are in breach of Malaysian employment law and Article 9 of the Protection of Wages Convention, 106 which Malaysia has ratified107 and which prohibits "any deduction from wages with a view to ensuring a direct or indirect payment for the purpose of obtaining or retaining employment, made by a labour to an employer or his representative or to any intermediary (such as a labour contractor or recruiter)". Families are also subjected to debt to pay for recruitment fees to at least get the labour migrant in the labour outsourcing system. (U.S. State Department. Trafficking in Persons Report, 2011) 
2. Unawareness of Labour Rights- Migrant labour often not aware of their (labour) rights. If they wanted to exercise the (limited) rights they have or seek redress in case of violations, they face tough obstacles. Employers can dismiss and revoke the work permit of migrant labours if they file a complaint, making them vulnerable to arrest, fines, imprisonment and deportation due to a lack of a working permit. The Labours were threaten and intimidated to silent them. They were also not able to invest, including financially, in a long judicial process, especially when the outcome thereof is uncertain. Malaysian law makes it illegal for a migrant labour to remain in the country once a contract has been terminated, so that access to justice is made effectively impossible.

3. Low Wages- Manipulation and non -payment.-They are being forced to work long hours, while being paid much less than they were promised by their recruiters (Bormann et al.,2009). When outsourced they were not protected by any collective agreements or bonus systems. They were expected to meet production quotas without extra payment and threaten with deportation and wage deduction becomes a means to penalize mistakes and inefficiency by the migrant labour.(make IT fair,2013). Manipulation of employment contract content further victimize an ignorant labour (Borman et al.,2009). This violates ILO Convention No. 95, which was ratified by Malaysia.

Article 8.2, provides that;

"labours shall be informed, in the manner deemed most appropriate by the competent authority, of the conditions under which and the extent to which such deductions may be made."

Delayed salaries and non-payment of wages also violates ILO Convention No. 95, Article 12, which states that "wages shall be paid regularly. Except where other appropriate arrangements exist which ensure the payment of wages at regular intervals, the intervals for the payment of wages shall be prescribed by national laws or regulations or fixed by collective agreement or arbitration award" (ILO,1949).

4. Rights to basic needs

The Memoranda of Understanding between Malaysia and home countries states that employers are obliged to provide migrant labours with accommodation, free access to water and electricity as well as transportation to the factory (Borrman, 2009). Outsourcing leads to further migrant labour dependency to agents, threats such as wage deductions for illness, become homeless and lose his or her work permit, and can even be a ground to terminate labours' contracts. Agencies are legally obliged to cover the medical treatment of employees but in reality their wages are deducted for medical expenses.

\section{E. HUMAN TRAFFICKING AND SMUGGLING OF PERSONS}

Foreign Migrant Labour Outsourcing System will obviously boost Human Trafficking and Smuggling of Persons activities into Malaysia. That is when massive power is given to outsourcing agencies and it is well known that there will always be unscrupulous agents. Their main focus is profiteering because outsourcing is a business, therefore it is foreseeable that these labour may be abused and victimized all through the migration processes that are; during the recruitment, transportation, transfer, harbouring or receipt of persons at the destination country. They facethreat or useforce or other forms of coercion, of abduction, of fraud, of deception, of the abuse of power or of a position of vulnerability or of the giving or receiving of payments or benefits to achieve the consent of a person having control over the migrants labour for the purpose of exploitation (Article 3(a) of the Protocol to the United Nations Convention against Transnational Organized Crime (Protocol to Prevent, Suppress and Punish Trafficking in Persons)) 
In its 2012 U.S. Department of State Trafficking in Persons (TIP) Report it is highlighted that the recruitment agencies are recognised as playing a central role in human trafficking. Their misconduct (such as providing false information about the nature of the work, withholding passports charging illegal fees, etc.) may amount to constituting human trafficking. In 2010 and 2011, Malaysia was promoted to Tier 2 (Watch List) but some of the Trafficking Victims Protection Act's (TVPA) Minimum Standard are yet to be realized. These are stated as follows;

(Malaysia is categorized as)Countries whose governments do not fully comply with the TVPA's minimum standards, but are making significant efforts to bring themselves into compliance with those standards AND:

a) The absolute number of victims of severe forms of trafficking is very significant or is significantly increasing;

b) There is a failure to provide evidence of increasing efforts to combat severe forms of trafficking in persons from the previous year; or

c) The determination that a country is making significant efforts to bring itself into compliance with minimum standards was based on commitments by the country to take additional future steps over the next year (U.S Dept, 2013).

\section{CONCLUSIONS}

In conclusions, outsourcing of migrant labour may have great benefits to the government and the outsourcing agencies but may not be friendly enough for the migrant labours. Being ignorant in many of the complex procedural processes caused the migrant labour, prone to be cheated financially, mislead and, misrepresented of the necessary information, abused and victimized physically, psychologically and sexually. However, in Europe (the Acquired Rights Directive)and United States of America(Trade Adjustment Assistance Act) were enacted to compensate labours affected by outsourcing and international trade agreements. (Baldwin,2006). On the other hand, Mexico experienced improvement of her economy via labour outsourcing. Economic growth requires change, therefore governance disposed to helping social and economic structures adapt to the changing environment will facilitate growth and a stable transition to new economic structures (Hanson,2003).For underdeveloped and developing countries, outsourcing is seen as a logical answer to move towards "open markets" and "trade liberalization." Moreover it complements trade liberalization strategies not only by promoting technological spillovers and capital inflows but also by offsetting the increasing levels of unemployment which result from opening up domestic markets.

\section{REFERENCES}

Amnesty International. (2010) Trapped. The Exploitation of Migrant Workers in Malaysia. London: Amnesty Publications. http://www.amnesty.org/en/library/info/ASA28/002/2010.

Antara News. "ASEAN Urged to Adopt Legally Binding Agreement on Workers". Retrieved from

April-June 2011 Retrieved from http://www.antaranews.com/en/news/70164/asean-urged-to-adoptlegally-binding-agreement-on-workers

Baldwin,Richard. (2006). Globalisation: the great unbludning(s), Chapter 1, in Globalization Challenges for Europe, Secretariat of the Economic Council, Finnish Prime Minister's Office, Helsinki, 2006 
Bhopal, M., \& Rowley, C. "The State in employment: the case of Malaysian Electronics", The International Bormann, S., Krishnan, P., \&Neuner, M. (2009). Migrants in a Digital Age. Migrant Workers in the Malaysian

Bormann, S., Krishnan, P., \&Neuner, M. (2009). Migrants in a Digital Age. Migrant Workers in the Malaysian

Buchholz, Todd G. Bringing the Jobs Home: How the Left Created the Outsourcing Crisis - and How We Can Fix It. New York: Sentinel, 2004. Print 97-118.

Council Review of the Trade Policies in Malaysia, 2010). p. 2. Retrieved from http:// www. ituccsi.

Crinis, V. (2002) "The Stratification of the Garment and Textile and Labour Movements in Malaysia," in N. Piper and D. Gills (eds), Women and Work in Industrialising Asia, London: Routledge, pp. $154-68$

Crinis, V. ,Sweat or No Sweat: Foreign Labours in the Garment Industry in Malaysia, Journal of Contemporary Asia, Vol. 40, No. 4, November 2010, pp. 589-611

Davies, Paul. What's This India Business?: Offshoring, Outsourcing, and the Global Services Revolution. London: Nicholas Brealey International, 2004. Print.

Electronics Industry: Case Studies on Jabil Circuit and Flextronics. WEED. Berlin. http://www2.weedonline.employees of unionized companies', Indian Journal of Industrial Relations, 2011, vol. 46, issue 3.

ETP-A Roadmap for Malaysia, Handbook Chapter 1-4- New Economic Model of Malaysia, http://etp.pemandu.gov.my/upload/etp_handbook_chapter_1-4_economic_model .pdf

FIDH / SUARAM, Undocumented Migrants and Refugees in Malaysia: Raids, Detention and Discrimination(2008). Retrieved from http://www.fidh.org/IMG/pdf/MalaisieCONJ489eng.pdf $p$. 7.

For a current list of Malaysia's ratifications, see the ILO website:http://www.ilo .org/ dyn/ normlex len/f?p=1000:11200:0::NO:11200 :P11200 COUNTRY ID: 102960

Foreign Labours in Malaysia: Assessment of their Economic Effects and Review of the Policy, International Population Conference on Migration, Urbanization and Development

Forey, Gail, and Jane Lockwood. Globalization, Communication and the Workplace: Talking across the World. New York: Continuum, 2011. Electronic Book \#21-26.

Hanson, G. (2003), "What Has Happened to Wages in Mexico Since NAFTA", NBER Working Paper Series, National Bureau of Economic Research, Cambridge, MA.

Hassan, K.H., \& George, C.M. (2009), External Migration of Labour Force and Access to Justice: Malaysian Law in the Context of ILO Standards, part of the research project "Transformation of Dispute Resolution Mechanism Towards Social Justice" (Malaysian Ministry of Higher Education). pp. 5-7. 
Hector, C. (2011). 'Outsourcing Agents and Their Practices: An 'Illegality' and Injustice that Must End.

Hira, Ron, and Anil Hira. Outsourcing America: What's behind Our National Crisis and How We Can Reclaim American Jobs? New York: AMACOM, 2008. Print \# 67-96.

ILO. "ILO Declaration on Fundamental Principles and Rights at Work and Its Follow-up. Article. 2," ILO in the Context of ILO Standards, part of the research project "Transformation of Dispute Resolution Mechanism International Monetary Fund. (2000). "Globalization: Threats or Opportunity."

12th April 2000: IMF Publications

International Monetary Fund . (2000). Globalization: Threats or Opportunity. 12th April 2000: IMF Publications

Investor friendly measure. Cited in Malaysian Trades Union Congress (MTUC IR Committee) 12.08.2010. p. 3.

ITUC. Internationally Recognised Core Labour Standards in Malaysia (Geneva: Report for the WTO GeneralJournal of Human Resource Management 13 no. 8 (2002): 1173; Malaysia's stance was reaffirmed in 2008 whenJuly 8th, 2013 http://psu.um.edu.my/images/psu/doc/

makelTfair, see http://makeitfair.org.

More Than 2.3 Million Foreigners Registered Under 6P Programme http://mapo.bernama.com/news.php?id=611630 29 March 2014

NirJaimovich and Henry E. Siu, "The Trend is the Cycle: Job Polarization and Jobless Recoveries," NBER Working Paper No. 18334, August, 2012.http://www.nber.org/papers/w18334

U.StateDept, Office To Monitor And Combat Trafficking In Persons, Trafficking In Persons Report $\underline{2013}$ Http://Www.State.Gov/J/Tip

Olive, B (2004). "Outsourcing Growing, Despite Controversy". Power. 148(4), 1920.org/lMG/pdf/CLS_Malaysia_2010_clean_final_def.pdf org/uploads/migration_in_a_digital_age.pdf

Overby, S (2007) ABC: An Introduction to Outsourcing. CIO.com.phase, 'enforcement bodies are ready to weed illegals out of their hiding places and those working in unapproved Publications. http://www.amnesty.org/en/library/info/ASA28/002/2010. http://www.unhcr.org/refworld/country,USCRI,,IDN,,4a40d2adc,0.html Retrieved from

Rose, C.R., Kumar, N,. \& Ramasamy, N. (2011). 'Trade unions in Malaysia: perspectives of employers \&sectors'. "Time to weed out the illegals". Retrieved from http://www.nst.com.my/nation/general/time-to-weedout-

SOMO Research (2011) SOMO Research: Working and Living Conditions of Migrant Workers in the Electronic Sector in Malaysia: 36

The New Strait Times reported on 12 April 2012 that with the 6P programme now entering the enforcement phase, 'enforcement bodies are ready to weed illegals out of their hiding places 
and those working in unapproved sectors'. "Time to weed out the illegals". Retrieved from http://www. nst.com.my/nation/general/time-to-weedout-the-illegals-1.73181

The World Bank, East Asia Pacific Region, Human Development Dept. Social Protection \& Labour Unit the-illegals-1.73181

Towards Social Justice (Malaysian Ministry of Higher Education). pp. 5-7.

U.S. State Department. Trafficking in Persons Report 2011. Retrieved from http://www.state. gov/g/tip/ rls/tiprpt/2011/index.htm p. 8.

UNHCR country operations profile 2012 - Malaysia. Retrieved from United States Committee for Refugees and Immigrants (17.6.2009) World Refugee Survey 2009 - Malaysia. 